\title{
PERBUATAN MEMBELA AGAMA MENURUT KONSEP KITAB UNDANG-UNDANG HUKUM PIDANA (KUHP)
}

\author{
Rani Dewi Kurniawati ${ }^{1}$ \\ Zuraidah $^{2}$
}

\begin{abstract}
ABSTRAK
Kebebasan beragama di negara kita telah di jamin dalam UUD 1945, namun dalam menjalankan peribadatan agama, tidak menutup kemungkinan terjadinya pembenaran adanya aksi-aksi yang bersifat melukai, represif serta destruktif dan mencedari hukum yang berlaku di Indonesia atas dasar agama

Metode Penelitian Hukum yang digunakan adalah penelitian Hukum Normatif atau penelitian hukum kepustakaan yaitu suatu jenis penelitian hukum yang diperoleh dari studi kepustakaan dengan menganalisis suatu permasalahan hukum melalui perundang-undangan, literatur-literatur dan pendekatan kasus yang memiliki kesamaan tema dengan judul yang dibahas oleh penulis.

Hasil dari penelitian hukum ini menjelaskan bahwa apakah perbuatan membela agama dapat dikualifikasikan sebagai tindak pidana, yaitu dapat dikatakan sebagai tindak pidana saat perbuatan membela agama tersebut dilakukan dengan menggunakan cara yang bertentangan dengan hukum yang berlaku atau dengan kata lain ada peraturan Undang-undang yang dilanggar dari perbuatan membela agama tersebut, akan tetapi akan berbeda disaat perbuatan membela agama ini dilakukan berdasar pada peraturan hukum yang berlaku, saat seseorang melihat atau menyaksikan ataupn mendengar telah terjadi perbuatan penodaan agama, maka laporkan hal itu kepihak yang bewajib dan biarkanlah penegak hukum menjalankan kewajibannya, masyarakat hanya sebatas melaporkan dan menunggu seperti apa penegak hukum melakukan fungsinya masing-masing dan permasalahan apakah dalam perbuatan membela agama ini dapat diterapkan alasan penghapus pidana, dan jawabannya yaitu tidak dapat diterapkan alasan penghapus pidana, tiap kasus perbuatan membela agama dilakukan secara sadar dan berdasarkan kemauan yang bersangkutan sehingga secara unsur terpenuhi.
\end{abstract}

\section{Kata Kunci : Membela, Agama, Pidana, Penghapus}

\footnotetext{
${ }^{1}$ Dosen Fakultas Hukum Universitas Majalengka, email rani.dewikurniawati@gmail.com

${ }^{2}$ Dosen Fakultas Hukum Universitas Majalengka,email : zuraidahsyahdan@gmail.com
} 
PRESUMPTION of LAW

Fakultas Hukum Universitas Majalengka

Volume 3 Nomor 1 April 2021

\section{A. Latar Belakang}

Indonesia adalah Negara demoktratis yang memiliki kebhinekaan yang beragam dari ras, suku dan agama. Kepluralan tersebut dapat berdampingan hidup dengan damai, tanpa adanya pergesakan berarti dari semenjak masa Indonesia merdeka sampai tumbuhnya pemahaman-pemahaman berbeda dalam menyikapi suatu perbedaan. Dalam masa 10 tahun terakhir menjadi familiar aksi-aksi yang mencederai perbedaan yang setelah kurun waktu dapat berdampingan secara damai di Indonesia. Bermunculannya beberapa kelompok islam yang 'esktrim' yang melakukan perbuatan-perbuatan yang dianggap kelompok ini sebagai tindakan bela agama dengan cara represif. Sering kita mendengar alasan, atau tepatnya klaim, sejumlah kelompok "Islam ekstrim" ketika melakukan aksi-aksi kekerasan (baik kekerasan fisik, kultural, maupun simbolik) terhadap berbagai kelompok agama di luar mereka (baik non-Muslim maupun kaum Muslim itu sendiri) adalah demi membela agama (Islam) atau demi membela Kitab Suci (Al-Qur'an). Dan yang lebih "fenomenal" lagi, demi membela Tuhan (Allah SWT).

Lebih tepatnya, aksi-aksi kekerasan yang mereka lakukan itu sering kali, jika bukan selalu, untuk membela tafsir (tentang) agama bukan agama itu sendiri, untuk membela tafsir (tentang) Kitab Suci bukan Kitab Suci itu sendiri, serta untuk mempertahankan tafsir (tentang) Tuhan, bukan Tuhan itu sendiri. Tidak sebatas itu, bahkan sering kali kekerasan komunal antarpemeluk agama atau kekerasan atas pemeluk agama tertentu dipicu oleh faktor-faktor yang sama sekali tidak ada sangkut-pautnya dengan ajaran, doktrin, dan normanorma keagamaan. Kekerasan juga sering kali demi menuruti hawa nafsu dan egoisme kelompok tertentu umat beragama, tidak ada korelasinya dengan ajaran-ajaran fundamental agama. Teks-teks keagamaan hanya dicatut atau dipakai sebagai pembenar seolah-olah tindakan beringas dan konyol yang mereka lakukan itu mendapat "mandat" atau restu dari Tuhan. Misalnya, apakah masalah toa (loudspeaker) masjid itu ada hubungannya dengan ajaran agama Islam? Sama sekali tidak ada, bukan? Toa adalah barang profan-sekuler bukan sakral-agamis karena ia merupakan produk kebudayaan manusia, tepatnya manusia kontemporer. Nabi Muhammad sendiri jelas tidak pernah memakai toa karena memang waktu itu belum ada teknologi pengeras suara ini. Tetapi kenapa gara-gara "insiden toa", sekelompok umat Islam di Tanjung Balai, Sumatra Utara, bisa menjadi kalap dan gelap mata melakukan pengrusakan atas sejumlah kelenteng dan wihara? Apakah aksi-aksi kekerasan dalam bentuk penjarahan dan vandalisme itu merupakan tindakan pembelaan sebuah agama atau nilai-nilai keislaman? Itu adalah satu dari sekian banyak aksi/perbuatan yang memeperlihatkan kebarbaran dalam rangka melakukan perbuatan yang mereka klaim sebagai tindakan 'membela agama'. Hal lain misalnya tentang status "kesesatan" umat agama atau pemeluk sekte keislaman tertentu yang juga sering dijadikan sebagai argumen oleh sejumlah kelompok "Islam ekstrim" untuk melakukan aneka tindakan kekerasan, lagi-lagi, atas nama (membela kemurnian) agama, Kitab Suci, dan Tuhan. Padahal, label sesat, kafir, bid'ah dan semacamnya adalah jelas hanyalah sebuah tafsir atas 
PRESUMPTION of LAW

Fakultas Hukum Universitas Majalengka

Volume 3 Nomor 1 April 2021

teks, ajaran, diskursus, dan sejarah keagamaan yang bersifat terbatas, relatifsubyektif dan bahkan politis.

Terbatas karena tidak semua kawasan dimana umat Islam tinggal ikut menuding sesat sebuah kelompok atau sekte yang dianggap sesat oleh kelompok lain. Tentang Syiah dan Ahmadiyah misalnya yang sering dikafirsesatkan oleh sejumlah kelompok Islam ternyata banyak daerah dan negara di dunia ini yang sangat "welcome" dengan mereka.

Di Wonosobo (begitu pula di daerah-daerah lain di Jawa Tengah seperti Semarang, Jepara dan sebagainya) umat Syiah dan Ahmadiyah hidup ademayem dengan umat lain. Di Qatar dan Oman, warga Syiah juga hidup dengan aman dan nyaman berdampingan dengan pemeluk Sunni dan Ibadi sebagai kelompok mayoritas di kedua negara di kawasan Arab Teluk ini. Begitu pula di berbagai kawasan Islam di China dan Asia Tengah, lebih-lebih di negaranegara Barat, umat Islam hampir-hampir tidak mempersoalkan sama sekali "status teologis" atau "legalitas keislaman" Syiah, Ahmadiyah dan sekte-sekte keislaman lain. Status "kafir-sesat" juga sangat relatif-subyektif karena terbukti tidak semua umat Islam turut mengkafir-sesatkan sebuah kelompok atau sekte keagamaan tertentu. Kita bisa saja memandang sesat atas praktik keagamaan orang lain. Tetapi sadarkah kita bahwa orang lain itu juga bisa jadi memandang sesat terhadap praktik keagamaan yang kita lakukan. Jadi tidak ada label "kafir-sesat" yang bersifat "obyektif" dan "inheren" karena faktanya apa yang kita anggap "benar" dan "legitimate" itu belum tentu dianggap "benar" dan "legitimate" di mata orang lain.

Sering diklaim oleh (sebagian) umat Islam sebagai "nilai-nilai agama" yang dinilai suci dan religius dan dibela mati-matian bahkan sampai rela melakukan kekerasan dan beragam kejahatan kemanusiaan itu pada dasarnya adalah sebuah "nilai-nilai budaya" yang bersifat sekuler dan profan. Pasalnya semua itu merupakan hasil interpretasi dan rekonstruksi pemikiran elit individu (seperti ulama dan fuqaha atau ahli Hukum Islam) serta produk sejarah pengalaman kemanusiaan dan kemasyarakatan kaum Muslim saat bersinggungan dengan fakta-fakta sosial-politik-kebudayaan sekitar. Karena itu, sekali lagi, bukan agama melainkan tafsir agama yang sering kali menjadi sumber pemicu dan peletup beragam kekerasan dan tindakan intoleransi yang dilakukan oleh sejumlah kelompok agama radikal-konservatif di masyarakat. Masalah baru muncul yang besebrangan dengan keyakinan seorang penganut agama dengan hukum yang berlaku di Negara di mana pelaku tersebut hidup dan tumbuh. Khususnya di Indonesia yang ruh asasnya berdasarkan piagam Jakarta yaitu ketuhanan yang maha Esa tapi tetap yang berlaku adalah asas yang umum yaitu Indonesia adalah Negara hukum bukan Negara yang berlandaskan agama. Di Negara ini setiap warna Negara dijamin hak-hak asasinya untuk dijalankan, baik dalam peribadatan, mengungkapkan pendapat dan hak-hak asasi lain yang secara konstitusional diatur dan harus dihormati.

Keironisan ini membuat peneliti tertarik meneliti tentang bagaimana hukum normative kita mengakomodasi tindakan-tindakan repsesif seperti ini dalam rangka membela agama, dengan demikian peneliti memutuskan mengangkat judul artikel hukum sebagai berikut " 
PRESUMPTION of LAW

Fakultas Hukum Universitas Majalengka

Volume 3 Nomor 1 April 2021

\section{PERBUATAN MEMBELA AGAMA MENURUT KONSEP KITAB UNDANG-UNDANG HUKUM PIDANA (KUHP)",}

B. Rumusan Masalah/ Identifikasi Masalah

1. Apakah Perbuatan dalam membela agama dapat diklasifikasikan sebagai tindak Pidana dalam konstruksi Hukum Pidana ?

2. Apakah alasan untuk membela agama dapat dikualifikasikan sebagai alasan penghapus pidana?

\section{Tujuan penelitian}

1. Untuk menganalisa tentang penerapan hukum khususnya dalam kitab Undang-undang Hukum Pidana (KUHP) terhadap setiap perbuatan dalam rangka membela agama.

2. Memberikan edukasi berupa pemahaman yang benar kepada warga Negara yang juga penganut agama tentang bagaimana limitasi tentang konsep bela agama dalam pemahaman Islam itu sendiri dan pengaturannya dalam hukum normatif yang berlaku di Indonesia .

\section{Metode Penelitian}

1. Jenis Penelitian

Jenis penelitian dalam penelitian hukum ini adalah penelitian hukum normatif. Menurut Terry Hutchinson sebagaimana dikutip Peter Mahmud Marzuki mendefinisikan bahwa penelitian hukum Normatif adalah sebagai berikut :

"research wich provides a systematic exposition of the rules goverming a particular legal kategory, analyses the relationship between rules, explain areas of difficullty and, perhaps, predicts future development."

(Penelitia Normatif adalah penelitian yang memberikan penjelasan sistematis aturan yang mengatur suatu kategori hukum tertentu, menganalisis hubungan antara peraturan menjelaskan daerah kesulitan dan mungkin memprediksi pembangunan masa depan). ${ }^{3}$

Penelitian hukum normatif yang nama lainnya adalah penelitian hukum doktrinal yang disebut juga sebagai penelitian perpustakaan atau studi dokumen karena penelitian ini dilakukan atau ditujukan hanya pada peraturan-peraturan yang tertulis atau bahan-bahan hukum yang lain ${ }^{4}$. Pada intinya penelitian yang dilakukan dengan cara meneliti bahan-bahan pustaka atau data sekunder yang terdiri dari bahan hukum primer, bahan hukum sekunder dan bahan hukum tertier.

2. Tipe Penelitian

Tipe penelitian hukum normative yang tipenya reform oriented, peneliti menilai diperlukannya perubahan/reformasi peraturan yang mengatur tentang perbuatan membela agama dalam konstruksi hukum normatif di Indonesia, dengan segera mengundangkan RKUHP yang dapat

\footnotetext{
${ }^{3}$ Peter Mahmud Marzuki,Penelitian Hukum, Kencana Prenada Media Group, Jakarta, 2011, hlm 32

${ }^{4}$ Soerjono Soekanto, dan Sri Mamudji, Penelitian Hukum Normatif, Cetakan ke-8, PT. Raja Grafindo Persada, Jakarta, 2004, hlm. 14
} 
PRESUMPTION of LAW

Fakultas Hukum Universitas Majalengka

Volume 3 Nomor 1 April 2021

meminimakan perbuatan penodaan agama yang sebagai awal asal mula adanya perbuatan membela agama dimasyarakat. Juga penelitian terhadap sistematika hukum dan penelitian terhadap taraf sinkronisasi verikal dan horizontal. Oleh sebab itu pada penelitian Normatif yang fokus kepada studi kepustakaan dengan menggunakan berbagai sumber data sekunder seperti pasal-pasal PerUndang-undangan berbagai teori hukum.

3. Pendekatan penelitian

a. Pendekatan konseptual (conceptual approach)

Mengutip Peter Mahmud Marzuki, ${ }^{5}$ bahwa pendekatan konseptual berpijak dari pandangan-pandangan dan doktrin-doktrin yang berkembang di dalam ilmu hukum. Pemahaman terhadap doktrin dan pandangan-pandangan diharapkan menimbulkan ide sehingga melahirkan pengertian-pengertian, konsep-konsep, dan asas-asas hukum yang relevan dengan isu yang dihadapi.Doktrin dan pandangan-pandangan merupakan sandaran dalam membangun suatu argumentasi hukum dalam memecahkan masalah. Permasalahan dalam penelitian ini upaya represif yang dilakukan oleh golongan tertentu dengan dalih membela agama itu secara agama memang dibenarkan akan tetapi ada asas-asas hukum yang berlaku di Indonesia yang mengatur dengan tegas dan jelas upaya hukum apa yang bisa diupayakan apabila ditemukan suatu perbuatan yang dinilai bertentangan terhadap nilai suatu agama. Indonesia adalah Negara hukum bukan Negara Islam.

b. Pendekatan Undang-Undang

Peter Mahmud Marzuki ${ }^{6}$ menyatakan pendekatan perundang-undangan dilakukan dengan menelaah semua undang-undang dan regulasi yang bertalian dengan isu hukum yang sedang ditangani. Pendekatan perundang-undangan harus dimaknai lebih luas bukan hanya sekedar undang-undang sebagai nomenklatur, namun undang-undang sebagai entitas norma hukum. Pendekatan perundang-undangan mengantarkan penulis pada pencarian rasio legis dan dasar ontologislahirnya undangundang yang bersangkutan.Usaha mempelajari rasio legis dan dasar ontologis suatu undang-undang diharapkan mampu menangkap kandungan filosofi yang ada dalam undang-undang sehingga dengan demikian dapat ditarik kesimpulan mengenai ada tidaknya benturan filosofis antara undang-undang dengan isu yang dihadapi.

Dalam penelitian ini peraturan yang peneliti pakai adalah Al-quran, hadist-hadist shahih, Undang-undang Dasar 1945, Kitab Undang-undang Hukum Pidana, Undang-undang Nomor 39 Tahun 1999 tentang Hak Asasi Manusia, Lembaran Negara Republik Indonesia Nomor 165 Tahun 1999

\footnotetext{
${ }^{5}$ Peter Mahmud Marzuki, , Penelitian Hukum, Kencana, Jakarta, 2005, hlm. 95.

${ }^{6}$ Ibid., hlm. 93.
} 
PRESUMPTION of LAW

Fakultas Hukum Universitas Majalengka

Volume 3 Nomor 1 April 2021

\section{E. Kerangka Pemikiran}

Bhinneka adalah salah satu unsur yang dimiliki oleh masyarakat Indonesia, dari suku, bahasa, ras dan terlebih agama. Menilik sejarah beragama di Indonesia yang menjadi concern dalam menelitian ini adalah tejadi perbedaan yang signifikan menurut penulis, pada saat dibawah tahun 1900 ke tahun 2000 disaat akses tentang ilmu agama terjadi keterbatasan dari sisi literasi dan kebijakan pemerintah yang tidak menjamin kebebasan dalam mengungkapkan pendapat serta mencari jawaban-jawaban dari pertanyaan kritis dari masyarakat. Kondisi yang demikian berbeda sekali denggan kondisi sekarang yang begitu mudah seseorang mengakses segala macam bentuk informasi sehingga kembali pada cara beragama seseorang karena sudah mendapatkan kepastian dari kebenaran dari ritual agama yang dilakukan selama ini. Demikian juga dalam mengungkapkan pendapat secara lisan maupun tulisan bagi penulis bahkan cenderung 'kebablasan' atau diluar batas kepatutan yang seharusnya seseorang lakukan. Hal ini tercermin dari semakin bermunculan tindakan-tindakan yang memicu suatu tindakan defensif yang cenderung represif karena adanya unsur yang 'dirasa' telah melakukan penghinaan terhadap suatu agama tertentu, sehingga sebagai akibatnya lahirlah tindakan membela agama sebagai dampak tindakan penghinaan terhadap agamanya. Islam sebagai agama mayoritas di Indonesia dan pada faktanya ada beberapa tindakan penodaan agama Islam yang sempat 'viral' dan dapat kita simak di media cetak maupun tertulis.

Penulis akan mencoba menginventarisir beberapa kasus penodaan agama yang memicu tindakan membela agama dan sempat menyita perhatian masyarakat Indonesia pada umumnya.

\section{Beberapa kasus tersebut sebagai berikut :}

1. Aksi Bela Islam 1,2 dan 3 sebagai dampak dari Perkataan Ahok pada kunjungan kerjanya (Kunker) di Kepulauan Seribu

2. Puisi Sukmawati : soal Konde,Kebaya dan cadar antara tren, tradisi dan identitas Puisi Sukmawati, yang kemudian menjadi kontroversi sampai membuatnya meminta maaf karena dianggap menyinggung umat Islam, mempertentangkan konde dengan cadar.

3. Aksi FPI dari Masa ke Masa ${ }^{7}$

Inilah beberapa aksi membela agama Islam versi Front Pembela Islam di Indonesia:

a. September 1999: Laskar Pembela Islam menutup tempat perjudian di Petojo Utara dan tempat pelacuran di Ciputat, Tanah Abang, Jakarta.

b. 4 Mei 2001: Kantor SCTV, Jakarta, diprotes FPI karena menayangkan telenovela Esmeralda, yang di dalamnya ada tokoh antagonis bernama Fatimah. FPI khawatir, citra buruk Fatimah dalam sinetron bisa mencitrakan hal yang sama pada Fatimah Azahra, putri Nabi. SCTV menghentikan tayangan telenovela.

7 Amirullah, https://nasional.tempo.co/read/383964/rentetan-aksi-fpi-dari-masa-kemasa/ full\&view = ok diakses tanggal 31 desember 2018 diakses jam 13.19. 
PRESUMPTION of LAW

Fakultas Hukum Universitas Majalengka

Volume 3 Nomor 1 April 2021

c. 20 April 2003: Ketua FPI Rizieq ditahan karena dianggap menghina polisi dalam dialog di SCTV dan Trans TV. Ia sempat dibawa kabur pendukungnya, tapi akhirnya divonis tujuh bulan kurungan.

1. Pengertian Penodaan Agama

Beberapa pakar hukum lebih memilih menggunakan kata cela atau mencela dibandingkan nista atau menista, perbedaan istilah tersebut disebabkan oleh penerjemahan kata smaad dari bahasa Belanda. Kesimpulannya, secara umum menistakan agama adalah perilaku, perbuatan yang menghinakan dan/atau merendahkan agama tertentu. ${ }^{8}$

2. Peraturan Tindak Pidana Terhadap Agama

Dalam redaksi berbeda arti dari tindak pidana terhadap agama adalah suatu tindakan yang secara sah menurut undang-undang yang berlaku adalah tindakan penodaan agama yang dilakukan oleh penganut agama itu sendiri atau penganut agama lain. Dalam KUHP (WvS) sebenarnya tidak ada bab khusus mengenai delik agama, meski ada beberapa delik yang sebenarnya dapat dikategorikan sebagai delik agama. Istilah delik agama itu sendiri sebenarnya mengandung beberapa pengertian:

a. delik menurut agama;

b. delik terhadap agama;

c. delik yang berhubungan dengan agama.

Penjelasan detail pasal perpasal yang terdapat dalam KUHP sebagai berikut :

1. Pasal 156 a dan b yang dijabarkan dalam Penetapan Presiden Republik Indonesia Nomor 1/PNPS Tahun 1965 tentang Pencegahan Penyalahgunaan dan/atau Penodaan Agama

Dipidanakan dengan pidana penjara selama-lamanya lima tahun barang siapa dengan sengaja di muka umum mengeluarkan perasaan atau melakukan perbuatan:

a. Yang pokoknya bersifat permusuhan, penyalahgunaan atau penodaan terhadap suatu agama yang dianut di Indonesia,

b. Dengan maksud agar supaya orang tidak menganut agama apapun juga, yang bersendikan Pada Tuhan yang Maha Esa.

Cara mengeluarkan perasaan atau melakukan perbuatan dapat dilakukan dengan lisan, tulisan ataupun perbuatan lain.

a. Tindak pidana yang dimaksudkan di sini ialah semata-mata (pada pokoknya) ditunjukkan kepada niat untuk memusuhi atau menghina.

b. Orang yang melakukan tindak pidana tersebut di sini, disamping mengganggu ketentraman orang beragama, pada dasarnya menghianati sila pertama dari negara secara total, dan oleh karenanya adalah pada temannya, bahwa perbuatannya itu dipidanakan sepantasnya.

8 Sadiq Adhetyo, "Delik Penistaan Agama Dalam Hukum Positif Indonesia", http://rajapena.org/delik-penistaan-agama-dal am-hukum-positif-indonesia/, diakses tanggal 31 desember 2018. 
PRESUMPTION of LAW

Fakultas Hukum Universitas Majalengka

Volume 3 Nomor 1 April 2021

2. Pasal 177 ayat 1 KUHP penghinaan terhadap petugas agama yang menjalankan

3. Pasal 503 menimbulkan gaduh di dekat tempat ibadah yang sedang digunakan beribadah

Selain peraturan tindak pidana terhadap agama dalam KUHP, juga terdapat peraturan tindak pidana agama diluar KUHP. Adapun penjelasan detail pasal perpasal yang terdapat diluar KUHP tentang tidak pidana terhadap Agama adalah Pasal 1 Penetapan Presiden Republik Indonesia Nomor 1/PNPS Tahun 1965 tentang Pencegahan Penyalahgunaan dan/atau Penodaan Agama. Pasal 4 Penetapan Presiden Republik Indonesia Nomor 1/PNPS Tahun 1965 tentang Pencegahan Penyalahgunaan dan/atau Penodaan Agama Pasal 4 Pada Kitab Undang-undang Hukum Pidana diadakan pasal baru yang berbunyi sebagai berikut: "Pasal 156a Dipidana dengan pidana penjara selamalamanya lima tahun barang siapa dengan sengaja di muka umum mengeluarkan perasaan atau melakukan perbuatan.

Suatu perbuatan tidak disebut sebagai tindak pidana selama tidak ada aturan yang dilanggar dengan perbuatan tersebut. Demikian juga apabila kita membahas suatu perbuatan yang dalam hal ini adalah perbuatan membela agama sebagai akibat dari suatu perbuatan yang dirasa/diduga telah melakukan penodaan/penghinaan terhadap agama tertentu. Pada realitas yang terjadi di Indonesia dalam kehidupan beragama masyarakatnya yang acapkali terjadi pergesekan secara vertika dan horizontal, dan penulis sudah menjabarkan diatas beberapa contoh kasus yang sangat menarik perhatian sebagaian besar masyarakat di Indonesia.

Perbuatan membela agama itu sendiri beragam bentuknya, ada yang sifatnya 'represif' tapi ada juga yang sifatanya 'damai'. Tentunya apabila kita berbicara tentang perbuatan membela Agama yang dikualifikasikan sebagai tindak pidana maka itu sangat bergantung dari bentuk tindakan/perbuatan membela agama yang dipilih oleh sipelaku, karena tindak pidana sendiri memiliki kekhususan yang terlah dirumuskan oleh ahli-ahli hukum Pidana di Indonesia yaang meliputi tindak pidana, unsur-unsur tindak pidana, syarat melawan hukum, kesalahan, percobaan dan gabungan tindak pidana. Penulis akan membahasnya dengan lebih rinci:

1. Tindak Pidana

Istilah tindak pidana merupakan terjemahan dari "strafbaar feit"perbuatan yang dilarang oleh suatu aturan hukum larangan dengan mana disertai ancaman (sanksi) yang berupa pidana tertentu, bagi barang siapa yang melanggar larangan tersebut. Delik tercantum dalam Kamus Besar Bahasa Indonesia sebagai berikut : "Delik adalah perbuatan yang dapat dikenakan hukuman karena merupakan pelanggaran terhadap undang-undang tindak pidana".

${ }^{9}$ Depdikbud Kamus Besar Bahasa Indonesia, cet. ke-2, Balai Pustaka, Jakarta, 1989. hlm. 219 
PRESUMPTION of LAW

Fakultas Hukum Universitas Majalengka

Volume 3 Nomor 1 April 2021

Pengertian tindak pidana adalah tindakan yang tidak hanya dirumuskan oleh KUHP. ${ }^{10}$

2. Syarat Melawan Hukum

Suatu perbuatan dikatakan melawan hukum apabila orang tersebut melanggar undang-undang yang ditetapkan oleh hukum. Tidak semua tindak pidana merupakan perbuatan melawan hukum karena ada alasan pembenar, berdasarkan Pasal 50, Pasal 51 KUHP.

3. Kesalahan

Berkaitan dalam asas hukum pidana yaitu Geen straf zonder schuld, actus non facit reum nisi mens sir rea, bahwa tidak dipidana jika tidak ada kesalahan, maka pengertian tindak pidana itu terpisah dengan yang dimaksud pertanggungjawaban tindak pidana.

4. Percobaan

Pada umumnya yang dimaksud dengan percobaan adalah suatu perbuatan dimana:

a. Ada perbuatan permulaan;

b. Perbuatan tersebut tidak selesai atau tujuan tidak tercapai;

c. Tidak selesainya perbuatan tersebut bukan karena kehendaknya sendiri

Syarat-syarat untuk dapat dipidananya percobaan adalah sebagai berikut:

a. Niat,

b. Adanya permulaan pelaksanaan,

c. Pelaksanaan tidak selesai bukan semata-mata karena kehendaknya sendiri.

Aturan pidana, menjadi sangat sempurna aturannya karena adanya aturan penghapus pidana, ada beberapa tipe tindak pidana/perbuatan pidana yang terjadi yang dapat diterapkan alasan penghapus pidana (alasaan pembenar ataupun pemaaf), penulis akan menjabarkan konsep tentang alasan penghapus pidana yang terdapat dalam KUHP, setelahnya akan penulis analisis bisa dan tidaknya ditetapakan alasan pembenar terhadap tindak pidana terhadap perbuatan membela agama.

Keadaan yang mengakibatkan seseorang melakukan perbuatan pidana tidak dipidana yang terletak di dalam Undang-Undang dapat dijelaskan melalui pendapat Memorie van Toelichting (MvT), Ilmu Pengetahuan, atau doktrin dalam hukum pidana.

Penjelasan :

1. Alasan Penghapus Pidana Yang Terletak Didalam Undang - Undang

Alasan penghapus pidana berdasarkan ilmu pengetahuan hukum pidana dibedakan menjadi 2 (dua), yaitu alasan penghapus pidana yang umum dan alasan penghapus pidana yang khusus :

${ }^{10}$ S.R. Sianturi, Asas-asas Hukum Pidana di Indonesia dan Penerapan, Cet. 3, Storia Grafika, Jakarta 2002, hlm. 204 
PRESUMPTION of LAW

Fakultas Hukum Universitas Majalengka

Volume 3 Nomor 1 April 2021

a. Alasan penghapus pidana yang umum merupakan alasan penghapus pidana yang berlaku untuk tiap-tiap delik pada umumnya sebagaimana disebut dalam pasal 44, 48 s/d 51 KUHP; sedangkan

b. Alasan penghapus pidana yang khusus, merupakan alasan yang hanya berlaku untuk delik- delik tertentu saja, seperti misalnya pasal 166 KUHP, Pasal 221 ayat 2 dan Pasal Pasal 310 ayat (3).

Berturut-turut dalam sub bab alasan penghapus pidana ini akan dibicarakan Pasal 44, 48, 49, 50 dan 51 KUHP :

a. Tidak Mampu Bertanggung Jawab (Pasal 44)

b. Daya Paksa (Overmacht) (pasal 48).

c. Keadaan Darurat (Noodtoestand)

d. Pembelaan Darurat (Noodweer) (Pasal 49)

e. Noodweer Exces (Pelampauan Batas Pembelaan Darurat) (Pasal 49 (2))

f. Menjalankan Peraturan Undang-Undang (pasal 50).

g. Melaksanakan Perintah Jabatan (pasal 51 ayat 1 dan 2)

2. Alasan Penghapus Pidana Yang Terletak Diluar Undang - Undang

Selain karena hal-hal atau keadaan yang diatur di dalam UU seseorang yang melakukan perbuatan pidana tidak di pidana.

Alasan Penghapus Pidana Putatief

Alasan penghapus pidana putative terjadi apabila seseorang mengira telah berbuat sesuatu dalam daya paksa atau dalam keadaan pembelaan darurat atau dalam menjalankan undang-undang atau dalam melaksanakan perintah jabatan yang sah, pada kenyataannya ialah tidak ada alasan penghapus pidana tersebut.

Penulis akan mulai sebagai berikut:

1. Penghina Agama Islam dan Hukumannya

Sikap dan tabiat "menghina" atau "menistakan" adalah akhlak para musuh Allah Azza wa Jalla yang menjadi akhlak orang kafir dan munafiqin. Oleh karena itu, Allah Azza wa Jalla menjelaskannya secara jelas kepada Rasulullah Shallallahu 'alaihi wa sallam dan para Sahabatnya dalam banyak ayat dan peristiwa. Dalam sejarah kehidupan Rasûlullâh Shallallahu 'alaihi wa sallam pernah terjadi dalam peristiwa perang Tabuk, kaum munafikin menghina para Sahabat Radhiyallahu anhum. Rasulullah Shallallahu 'alaihi wa sallam sebagai seorang yang paling sayang kepada manusia waktu itu tidak memaafkan dan tidak menerima uzur para penghina tersebut, bahkan tidak melihat alasan mereka sama sekali yang mengaku melakukannya sekedar bermain dan bercanda. Beliau Shallallahu 'alaihi wa sallam membacakan wahyu yang turun dari langit yang diabadikan dalam alQur`an, Firman Allah Azza wa Jalla :

Dan jika kamu tanyakan kepada mereka (tentang apa yang mereka lakukan itu), tentu mereka akan menjawab:"Sesungguhnya kami hanya bersenda gurau dan bermain-main saja". Katakanlah:"Apakah dengan Allah, ayatayat-Nya dan Rasûl-Nya kamu selalu berolok-olok?”. Tidak usah kamu minta maaf, karena kamu kafir sesudah beriman. Jika Kami mema'afkan 
PRESUMPTION of LAW

Fakultas Hukum Universitas Majalengka

Volume 3 Nomor 1 April 2021

segolongan dari kamu (lantaran mereka taubat), niscaya Kami akan mengadzab golongan (yang lain) di sebabkan mereka adalah orang-orang yang selalu berbuat dosa. [At-Taubah/9:66]

Oleh karena itu para Ulama memasukkan perbuatan menghina Allâh Azza wa Jalla , ayat suci dan Rasûl-Nya dalam pembatal keimanan.Syaikhul Islam Ibnu Taimiyah rahimahullah mengatakan bahwa menghina Allâh Azza wa Jalla, ayat suci dan Rasul-Nya adalah perbuatan kekafiran yang membuat pelakunya kafir setelah iman. ${ }^{11}$

2. Jenis Penghina Agama Islam

Islam secara umum membagi manusia menjadi tiga kelompok: kafir, munafik dan muslim. Semua jenis orang-orang ini sangat memungkinkan melakukan pencelaan dan penghinaan terhadap agama sehingga diperlukan mengetahui jenis dan hukuman dari penghina agama yang berdasarkan pembagiannya.

Yang wajib dan terbaik adalah mendengar dan mentaati mereka. Namun bukan berarti tidak ada amar ma'ruf nahi mungkar. Hal itu tetap ada tetapi harus dilakukan menurut kaedah yang telah ditetapkan oleh syariat yang mulia ini.

Sehingga bagi penulis jelaslah bahwa memahami agama ini memang tidak bisa Cuma dari satu sisi saja, tapi secara keseluruhan syariat yang telah ditentukan, maka tidak heran apabila kita begitu fanatik dengan satu hukum lalu mengabaikan hukum yang lain yang bahkan kedudukannya lebih tinggi dari hukum yang kita pahami sebelumnya. Diaplikasikan pada perbuatan membela Agama yang terbanyak terjadi adalah menghalalan tindakan anarkis, penuh dengan kekerasan dan tidak memanusiakan manusia sehingga wajar selama ini sejarah mencatat tak ada satu kasuspun di Indonesia yang mengatas namakan membela agama tapi ditetapkan asalan penghapus pidana dalam proses menghukuminya, hal ini beralasan karena secara hukum positif dan secara hukum agama tidak ada yang membenarkan tidakan represif, kekerasan, sweeping, perampasan dan lainnya. Boleh jadi kita menyaksikan suatu perbuatan yang menistakan syariat agama, tapi dalam hal ini pemerintah telah menyediakan sarana/prosedur yang sesuai sengan ketentuan hukum yang berlaku tidak dengan tidakan kekerasan, yang pasti akan menimbulkan kemudharatan lebih besar. Saat kita melihat /mendengar atau apapun yang berkaitan dengan penghinaan /pencelaan terhadap agama jangan melakukan tindakan seorang diri , melaporlah ke yang berwajib/berwenang untuk melakukan tindakan selanjutnya.

Perbuatan membela agama akan selalu muncul selama Penodaan agama termasuk dalam kejahatan kekerasan pada agama terus tejadi dan ini merupakan hal yang buruk karena agama mengajarkan nilai-nilai luhur.

\footnotetext{
${ }^{11}$ Ibnu Taimiyyah,Al-Fatâwa 7/273, Pustaka Azzam, 2016.
} 
PRESUMPTION of LAW

Fakultas Hukum Universitas Majalengka

Volume 3 Nomor 1 April 2021

Dalam pernyataannya tersebut, Juergensmeyer menilai bahwa sumber utama konflik dan kekerasan di dunia adalah agama. ${ }^{12}$ Meskipun penulis tidak sepenuhnya setuju dengan pernyataan ini tapi fakta lebih berkata banyak.

\section{F. Hasil Penelitianm dan Pembahasan}

\section{a. Refleksi tentang Penempatan Tindak Pidana terhadap Agama dan Kehidupan Beragama dalam KUHP.}

Pada mulanya tidak ada "Kejahatan terhadap Agama dan Kehidupan Beragama" yang diatur secara khusus dalam KUHP. Hanya saja terdapat beberapa rumusan delik yang dapat dipandang sebagai "kejahatan terhadap kehidupan beragama", yaitu dalam Pasal 175, 176 dan 177 KUHP. Sedangkan Pasal 156a KUHP yang didalamnya memuat rumusan delik tentang "kejahatan terhadap agama" merupakan "pasal amandemen" yang disisipkan berdasarkan Penetapan Presiden Republik Indonesia No. 1 Tahun 1965 Tentang Pencegahan Penyalahgunaan dan/atau Penodaaan Agama. Pada masa itu Penetapan Presiden (Penpres) merupakan produk hukum yang setara dengan undang-undang, yang sekarang dikenal dengan Peraturan Pemerintah Pengganti Undang-Undang (Perpu), sehingga diintrodusirnya hal ini dalam KUHP mencerminkan kebutuhan aktual masyarakat Indonesia. Baik Pasal 156a KUHP maupun Pasal 175, 176 dan 177 KUHP merupakan delik-delik yang berada dalam Bab V tentang "Kejahatan Terhadap Ketertiban Umum". Ketika tindak pidana terhadap agama dan kehidupan beragama ditempatkan dalam bab tentang kejahatan terhadap ketertiban umum, maka pada dasarnya "agama" atau "kehidupan beragama" bukan kepentingan utama yang hendak dilindungi dengan hukum pidana. Melainkan pelarangan atas perbuatan tersebut karena sangat berpotensi menggangu ketertiban umum.Sementara itu, dalam RKUHP tindak pidana ini ditempatkan dalam bab tersendiri. Dengan demikian, "agama" dan "kehidupan beragama" dipandang sebagai benda hukum tersendiri, yang merupakan kepentingan khusus bangsa dan karenanya diperlukan perlindungan tersendiri dengan ancaman pidana.

Berdasarkan hal ini, terdapat perkembangan yang mengadakan perubahan secara fundamental dari KUHP kepada RKUHP, terutama dalam melihat perbuatan-perbuatan yang "menista" suatu agama atau berbagai kegiatan peribadahan yang dilakukan pemeluknya. RKUHP menempatkan "agama" sebagai fundamen kehidupan bangsa, sehingga penodaan terhadap hal itu dipandang sebagai perbuatan tercela dan karenanya diancam pidana. Keleluasaan dalam menjalan "kehidupan beragama" bagi bangsa Indonesia merupakan hak dasar, sehingga segala gangguan terhadap hal itu harus dieliminasi. Masyarakat Indonesia yang religius menyebabkan pemeliharaan atas pola hidup demikian mutlak diperlukan. 
PRESUMPTION of LAW

Fakultas Hukum Universitas Majalengka

Volume 3 Nomor 1 April 2021

\section{b. Pembaruan Rumusan Tindak Pidana Penghinaan Terhadap Agama}

Dalam KUHP "kejahatan terhadap agama" ini dirumuskan: "Barang siapa dengan sengaja di muka umum mengeluarkan perasaan atau melakukan perbuatan yang pada pokoknya bersifat permusuhan, penyalahgunaan atau penodaan terhadap suatu agama yang dianut di Indonesia".

selain perumusan secara umum seperti itu, rumusan deliknya juga lebih dirinci dan dikonkritkan, yaitu dengan menggunakan perkataan "mengejek", "menodai", atau "merendahkan". Selain itu, mengingat "agama" adalah "benda hukum" yang abstrak, dalam RKUHP juga ditegaskan objek dari "penghinaan agama", yaitu dengan menggunakan kata-kata seperti "keagungan Tuhan", "firman (Tuhan)", "sifat-Nya", "rasul", "kitab suci", "ajaran agama", atau "ibadah keagamaan". Dalam hal tindak pidana penghinaan terhadap agama dilakukan dengan sarana percetakan atau rekaman, pidananya diperberat sebagaimana ditentukan dalam Pasal 344 ayat (1) RKUHP. Pemberatan ini lazim digunakan dalam hukum pidana seperti yang dianut dalam KUHP, dan tetap dipertahankan dalam RKUHP.

\section{c. Pembaruan Rumusan Tindak Pidana Penghasutan Untuk Meniadakan Keyakinan terhadap Agama}

KUHP menyebutkan tindak pidana dirumuskan sebagai berikut: "Barang siapa dengan sengaja di muka umum mengeluarkan perasaan atau melakukan perbuatan dengan maksud agar supaya orang tidak menganut agama apa pun juga, yang bersendikan Ketuhanan Yang Maha Esa”. Dalam Penjelasan Penpres No. 1 Tahun 1965, pengertian pasal ini ditentukan bahwa "orang melakukan tindak pidana tersebut disini, disamping menggangu ketentraman orang beragama, pada dasarnya mengkhianati sila pertama dari Negara secara total, dan oleh karenanya adalah pada tempatnya, bahwa perbuatan itu dipidana sepantasnya". Dalam RKUHP perkataan "mengeluarkan perasaan atau melakukan perbuatan" dikonkretisasi menjadi perbuatan "penghasutan". Perbuatan "penghasutan" juga merupakan mala in se, yang dirumuskan dalam Pasal 160 KUHP atau 288 s/d 290 RKUHP. Keberatan sebenarnya dapat diajukan terhadap perumusan bagian inti (bestanddeel) "agama yang di anut di Indonesia" yang maknanya lebih sempit daripada unsur "agama apapun juga" yang terdapat dalam KUHP.

\section{d. Pembaruan Tindak Pidana Gangguan tehadap Penyelenggaraan} Ibadah dan Kegiatan Keagamaan

Pasal 175 KUHP menentukan bahwa: "Barang siapa dengan kekerasan atau ancaman kekerasan merintangi pertemuan keagamaan yang bersifat umum dan diizinkan, atau upacara keagamaan yang diizinkan, atau upacara penguburan jenazah, diancam dengan pidana penjara paling lama satu tahun empat bulan" Dalam RKUHP delik ini ditempatkan dalam tindak pidana terhadap kehidupan beragama. Dalam hal ini, kriminalisasi diperluas sehingga mencakup pelarangan terhadap perbuatan yang "menggangu, 
PRESUMPTION of LAW

Fakultas Hukum Universitas Majalengka

Volume 3 Nomor 1 April 2021

merintangi, secara melawan hukum membubarkan dengan cara kekerasan atau ancaman kekerasan"

\section{e. Tindak Pidana perusakan Tempat Ibadah}

Pasal 348 RKUHP merupakan lex specialis dari Pasal 646 RKUHP tentang perusakan bagunan prasarana umum. Dalam hal ini ditentukan bahwa: "Setiap orang yang menodai atau secara melawan hukum merusak atau membakar bangunan tempat ibadah atau benda yang dipakai untuk ibadah, dipidana dengan pidana penjara paling lama 5 (lima) tahun atau denda paling banyak Kategori IV."

Keberatan dapat diajukan tentang perkataan "menodai", yang sebenarnya masuk kedalam tindak pidana terhadap agama dengan menambahkan "tempat dan/atau rumah ibadah" sebagai "simbol keagamaan" dalam Pasal 343 RKUHP. Selain itu, ancaman pidana dalam Pasal 348 mestinya lebih berat daripada Pasal 646, untuk memberi sifat kekhususannya.

Berdasarkan hal di atas, RKUHP telah mengadakan perubahan yang mengarah pada "konkretisasi" dan "objektifikasi" tindak pidana terhadap agama, sehingga prinsip lex certa dan lex stricta benar-benar diperhatikan. Pikiran-pikiran yang "mengkawatirkan" hal ini menjadi bentuk pembelengguan atau pembatasan hak untuk menyampaikan pendapat, pikiran atau gagasan.

Penulis berpendapat bahwa pengaturan yang jelas, rinci dan bersifat preventif adalah jawaban dari makin banyaknya tindakan Pidana terhadap agama yang terjadi sehingga perbuatan membela agama yang represif oleh sekelompok orang dapat dihindari atau bahkan dihilangkan.

\section{G. KESIMPULAN}

Berdasarkan penjabaran dan analisis yang dilakukan penulis di bab-bab sebelumnya, maka penulis bisa mengambil kesimpulan bahwa :

1. Perbuatan membela agama dapat diklasifikasikan sebagai tindak pidana apabila memenuhi unsur tindak pidana dari tiap perbuatannya. Sehingga Penulis berkesimpulan bahwa tiap-tiap perbuatan membela agama tidak bisa secara general tapi harus dianalisis berdasarkan kasusnya, karena kasus perbuatan pembelaan agama yang dilakukan oleh yang melaporkan kasus ahok berbeda dengan perbuatan membela agama yang dilakukan oleh salah satu Ormas yang memakai unsur kekerasan dalam rangka " membela agama", dan kasus-kasus inipun telah penulis terangkan pada bab sebelumnya bahwa dalam penghukumi setiap perbuatan dalam rangka membela agama dapat dilakukan dengan melakukan analisa tiap kasus karena tidak semua perbuatan membela agama dapat dikategorikan sebagai tindak pidana.

2. Perbuatan membela agama bagi setiap pemeluk agama adalah wajib. Termasuk dalam hal ini perbuatan membela agama yang dalam agama Islam ini adalah wajib tapi taat terhadap pemerintah adalah wajib, akan tetapi alasan ini tidak bisa dijadikan suatu alasan pembenar terhadap setiap perbuatan represif yang lahir dari perbuatan pembela agama ini karena 
Indonesia adalah negara hukum dan unsur untuk dimaafkannya tindakan tersebutpun secara hukum tidak bisa ditetapkaan karena unsur alasan penghapus pidananya tidak ada.

\section{H.Saran}

1. Melakukan Sosialisasi tentang konsep dan prosedur membela agama kepada masyarakat tentang bentuk dan jenis perbuatan membela agama yang dapat dilakukan oleh setiap warga negara.

2. Pasal-pasal baru dalam RKUHP yang pembahasan tentang Tindak Pidana terhadap agama yang memiliki isi yang lebih detail dan dapat mengakomodir setiap kondisi yang mungkin muncul dapat segera diUndangkan pada 2019 ini, sehingga bisa menjamin kenyamaanan tiap umat beragama dalam menjalankan hak beragamanya tanpa harus khawatir agamanya dilecehkan/hina oleh orang lain serta konflik secara horizontal dan vertikal pun bisa dihindari. 


\section{DAFTAR PUSTAKA}

\section{A. Sumber buku}

Depdikbud Kamus Besar Bahasa Indonesia, cet. ke-2 , Balai Pustaka, Jakarta, 1989.

Ibnu Taimiyyah,.Al-Fatâwa 7/273, Pustaka Azzam, 2016.

Peter Mahmud Marzuki, , Penelitian Hukum, Kencana, Jakarta, 2005.

,Penelitian Hukum, Kencana Prenada Media Group, Jakarta, 2011.

S.R. Sianturi, Asas-asas Hukum Pidana di Indonesia dan Penerapan, Cet. 3, Storia Grafika, Jakarta 2002.

Soerjono Soekanto, dan Sri Mamudji, Penelitian Hukum Normatif, Cetakan ke8, PT. Raja Grafindo Persada, Jakarta, 2004.

\section{B. Peraturan Perundang-undangan}

Al-quran,

Hadist-hadist shahih,

Undang-undang Dasar 1945,

Kitab Undang-Undang Hukum Pidana,

Kitab Undang-undang Hukum Acara Pidana

Undang-Undang Nomor 39 Tahun 1999 tentang Hak Asasi Manusia (Lembaran Negara Republik Indonesia Nomor 165Tahun 1999)

Penetapan Presiden Republik Indonesia Nomor 1/PNPS Tahun 1965 tentang Pencegahan Penyalahgunaan dan/atau Penodaan Agama.

Rancangan Kitab Undang-Undang Hukum Pidana . 
PRESUMPTION of LAW

Fakultas Hukum Universitas Majalengka

Volume 3 Nomor 1 April 2021

\section{Sumber Lain}

Amirullah, https://nasional.tempo.co/read/383964/rentetan-aksi-fpi-dari-masake-masa/ full\&view= ok diakses tanggal 31 desember 2018 diakses jam 13.19.

Sadiq Adhetyo, "Delik Penistaan Agama Dalam Hukum Positif Indonesia”, http://rajapena.org/delik-penistaan-agama-dalam-hukum-positifindonesia/, diakses tanggal 31 desember 2018. 